\title{
Prevention of endothelial dysfunction in streptozotocin-induced diabetic rats by Sargassum echinocarpum extract
}

\author{
Muhamad Firdaus, ${ }^{1}$ Made Astawan, ${ }^{2}$ Deddy Muchtadi, ${ }^{2}$ Tutik Wresdiyati, ${ }^{3}$ Sarwono Waspadji, ${ }^{4}$ Setyawati S. Karyono ${ }^{5}$ \\ ${ }^{1}$ Laboratory of Biochemistry, Faculty of Fisheries and Marine Science University of Brawijaya, Malang, Indonesia \\ ${ }^{2}$ Department of Food Science, Faculty of Agriculture Technology Bogor Agriculture University, Bogor, Indonesia \\ ${ }^{3}$ Laboratory of Anatomy, Faculty of Veterinary Bogor Agriculture University, Bogor, Indonesia \\ ${ }^{4}$ Internal Medicine Department, Faculty of Medicine University of Indonesia, Jakarta, Indonesia \\ ${ }^{5}$ Laboratory of Pharmacology, Faculty of Medicine University of Brawijaya, Malang, Indonesia
}

\begin{abstract}
Abstrak
Tujuan Untuk mengevaluasi efek ekstraks Sargassum echinocarpum sebagai pencegahan disfungsi sel endotel aorta torasis tikus diabetes yang diinduksi streptozotocin.

Metode Hewan uji dibagi lima kelompok, kelompok normal, diabetes dan diabetes yang diberi ekstrak rumput laut coklat (150, 300, dan $450 \mathrm{mg} / \mathrm{kg}$ BB per hari) diberikan selama 12 minggu setelah tikus mengalami diabetes. Diabetes diinduksi dengan streptozotocin (45 mg kg-1, i.p.) yang terlarut 0,1 M bufer sitrat, $\mathrm{pH}$ 4,5. Hewan uji dinyatakan diabetes pada hari kesepuluh setelah injeksi dan kadar gula darah menunjukkan $>200 \mathrm{mg}$ dL-1. Setelah masa perlakuan, serum darah diambil untuk uji antioksidan enzim dan aorta torasis untuk uji relaksasi.

Hasil Aktivitas superoksida dismutase (SOD), katalase (Kat), dan Glutation peroksidase (GSH-px) serum menurun. Pada tikus diabetes $(3,31 \pm 0,12 ; 67,17 \pm 0,62 ; 35,10 \pm 0,83)$ dibanding kontrol $(9,97 \pm 0,12 ; 185,31 \pm 0,23 ; 116,38 \pm 0,88)$. Pemberian ekstrak pàda tikus diabètes meningkatkan aktivitas SOD, Kat, dan GSH-px serum. Respons vasodilatasi terhadap asetil kolin mengalami penurunan signifikan dibanding tikus kontrol. Perbaikan respon terlihat pada tikus diabetes yang diberi ekstrak Sargassum echinocarpum .
\end{abstract}

Kesimpulan Ekstrak Sargassum echinocarpum memperbaiki stres oksidatif dan mencegah disfungsi endotel diabetes. Hal ini berkaitan sifat antioksidan ekstrak. (Med J Indones 2010; 19:32-5)

\begin{abstract}
Aim This study aimed to elicit the protective effect of Sargassum echinocarpum extract on endothelial dysfunction in thoracic aorta of streptozotocin-induced diabetic rats.

Methods The animals were divided into 5 groups. The first was normal, the second was diabetic non treated animals. The third to fifth groups were the diabetic animals which given Sargassum echinocarpum extract (150; 300, and 450 mg kg-1 body weight, respectively) by oral gavage and extract treatment was given for 12 weeks. Diabetes was induced by single administration of streptozotocin (45 mg kg-1, i.p.), dissolved in freshly prepared $0.1 \mathrm{M}$ citrate buffer, $\mathrm{pH} 4.5$. Diabetes was confirmed ten days latter in streptozotocin induced animals showing blood glucose levels $>200 \mathrm{mg}$ dL-1 $(11.1 \mathrm{mmol} \mathrm{L}-1)$ as monitored in the blood from tail vein using glucometer. After the treatment period, the blood serum acquired was used for antioxidant enzymes assays and the thoracic aorta was used for vasorelaxation assay.

Results There was a significant decrease in the activity of superoxide dismutase (SOD), catalase (CAT) and glutathione peroxidase (GSH-px) in diabetic rats $(3.31 \pm 0.12 ; 67.17 \pm 0.62 ; 35.10 \pm 0.83)$ comaped to control rats $(9.97 \pm 0.12 ; 185.31$ $\pm 0.23 ; 116.38 \pm 0.88)$. Administration of Sargassum extract increased the activity of SOD, CAT, and GSH-px. The diabetic rats exhibit endothelial dysfunction as shown by loss of vasodilatory response to acethylcholine (ACH). This was restored by administration of Sargassum extract.
\end{abstract}

Conclusion Sargassum echinocarpum extract ameliorates oxidative stress and reverses the endothelial dysfunction associated with diabetes. This effect appears to be due to its antioxidant properties. (Med J Indones 2010; 19:32-5)

Key words: oxidative stress, sargassum echinocarpum, endothelium dependent relaxation, thoracic aorta 
Oxidative stress has been defined as a disturbance in the balance between antioxidants and pro-oxidants. Hyperglycemia can induce oxidative stress by various mechanisms; excessive levels of glucose reaching the mitochondria lead to an overdrive of the electron transportchain, resultinginoverproduction of superoxide anions. When this radical scavenged by mitochondrial SOD fails, oxidative stress develops and it responsible for the activation of all major pathways underlying the vascular diabetic complications. ${ }^{1}$ The antioxidant defense may be lower in diabetes, which included reduced antioxidant status or free radical scavenging activity and this plays an important role in mediation of endothelial dysfunction accompanying diabetes. It seems reasonable to hipothesize that antioxidant treatment would prevent endothelial dysfunction in diabetes ${ }^{2,3}$

The relaxing response of aortic ring to Ach was decreased in untreated diabetic rats. ${ }^{4}$ This studies have clearly indicated that antioxidants may be beneficial in reducing oxidative stress and endothelial dysfunction in diabetes and eventually preventing the vasculopathy, which accounts for the majority of clinical complications in diabetes mellitus. ${ }^{4,5,6,7}$

Seaweeds have been habitually consumed on Indonesia, especially in coastal society. ${ }^{8}$ It has been reported that seaweeds contain a rich and largely untapped source of biologically active substances. ${ }^{9}$ Marine brown algae contain phloroglucinol phenolics ${ }^{10}$ which are probably good antioxidants, since plant phenolics can behave as ROS scavengers, metal chelators and enzymemodulators and prevent lipid peroxidation. ${ }^{11}$ The antioxidant

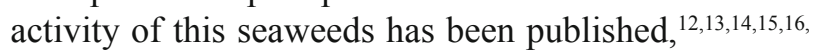
conversely, nowadays no experiment has been reported the effect of Sargassum echinocarpum extract on endothelial dysfunction in diabetic animal model.

The aim of this study was to investigate the protective effect of Sargassum echinocarpum extract on endothelial dysfunction in diabetic rats.

\section{METHODS}

Male Sprague-Dawley rats weighing 150-200 g were procured from Gajah Mada University, Indonesia. All procedures for treating animal were in accordance with the institutional guidelines for animal research, and approved by the animal research ethics committee of Brawijaya University, Indonesia. They were kept in clean and dry cages with a bedding of paddy husk, fed with normal diet and water ad libitum.
The animals were divided into 5 groups. The first was normal, the second was diabetic, and the others were diabetic which given extract. Diabetes was induced by single administration of streptozotocin $\left(45 \mathrm{mg} \mathrm{kg}^{-1}\right.$, i.p.), dissolved in freshly prepared $0.1 \mathrm{M}$ citrate buffer, $\mathrm{pH}$ 4.5. Diabetes was confirmed ten days latter in streptozotocin induced animals showing blood glucose levels > $200 \mathrm{mg} \mathrm{dL}-1$ (11.1 mmol L-1) as monitored in the blood from tail vein using glucometer. The third to fifth groups were the diabetic animals which given Sargassum echinocarpum extract (150; 300, and 450 $\mathrm{mg} \mathrm{kg}^{-1}$ body weight, respectively) by oral gavage and extract treatment was given for 12 weeks.

After the twelve weeks treatment period, the whole blood was obtained by cardiac puncture from the sacrificied rat. Blood was allowed to clot for $2 \mathrm{~h}$ and further centrifuged at 1500 RPM for $10 \mathrm{~min}$ to separate serum from the blood cells. The blood serum acquired was used for antioxidant enzymes assays.

Afterwards, the thoracic aorta (from the arch of aorta to diaphragma) was quickly excised and placed in ice cold carbogenated $\left(95 \% \mathrm{O}_{2}+5 \% \mathrm{CO}_{2}\right)$ Krebs Buffer $(\mathrm{KB})$. The aorta was cleaned of adhering fat and tissue and cut into 3-4 mm segments in length. Due care taken not to stretch the tissue or damage the endothelium. The composition (mM) of $\mathrm{KB}$ was $\mathrm{NaCl}: 136, \mathrm{KCl}: 5.4$, $\mathrm{MgSO}_{4} .7 \mathrm{H}_{2} \mathrm{O}: 0.5, \mathrm{CaCl}_{2}: 2.7, \mathrm{KH}_{2} \mathrm{PO}_{4}: 0.45, \mathrm{NaHCO}_{3}$ : 11.9 and glucose: 5.6 per liter

Each ring was suspended by a pair of 's' shaped stainless steel hooks in a water jacketed organ bath (10 mL, capacity), filled with $10 \mathrm{~mL}$ of carbogenated $\mathrm{KB}$ maintained at $37^{\circ} \mathrm{C}$. The segments were subjected to a tension of $1,5 \pm 0.5 \mathrm{~g}$ (optimal resting tension), which was readjusted every 15 min during a 90-min equilibration period before drug administration. After a washout period, each segment was contracted with $1 \mu \mathrm{M}$ noradrenaline (NA). Once a stable plateau was reached, a concentration-response curve to acetylcholine (Ach; $100 \mathrm{nM}$ to $5 \mathrm{mM}$ ) was performed. Changes in isometric tension were recorded using a force displacement transducer (Grass FT 0.3, Quincy, MA, USA) connected to a Power Lab system 400 (ML 118, PowerLab, AD Instruments, Medford, MA) and stored in a computer. Responses were expressed as percentage relaxation of NA induced contraction

The data were analyzed using SPSS version 16.0. Data are expressed as the mean \pm s.e.mean. The statistical differences were determined by Least Square Difference test, after a one-way analysis of variance, a probability level of $P<0.05$ being regarded as significant. 


\section{RESULTS}

The antioxidant enzymes were decreased in serum of the diabetic rats as compared with the normal. The diabetic group of rats, however, treated with Sargassum extract showed a significant increase in the activities of SOD, catalase and glutathione peroxidise in serum, respectively (Table 1).

Addition of $1 \mu \mathrm{M}$ NA to organ bath resulted in contraction of aorta of all groups. Isolated thoracic aorta rings precontracted with NA showed dose dependent relaxation to $\mathrm{ACh}(100 \mathrm{nM}$ to $5 \mathrm{mM})$. The nagnitude of relaxations was significantly reduced in diabetic rats when compared with normal. The aortic rings of diabetic rats treated with Sargassum echinocarpum extract showed significant relaxation as compared to the diabetic aortic rings (Figure 1).

Table 1. Effects of Sargassum extract on antioxidant enzymes activity in serum of rats

\begin{tabular}{lcrc}
\hline \multicolumn{1}{c}{ Groups } & \multicolumn{1}{c}{ SOD } & Cat & \multicolumn{1}{c}{ GPH-px } \\
\hline Control & $9.97 \pm 0.12^{*} 185.31 \pm 0.23^{*}$ & $116.38 \pm 0.88^{*}$ \\
Untreated Diabetic $3.31 \pm 0.12^{*}$ & $67.17 \pm 0.62^{*}$ & $35.10 \pm 0.83^{*}$ \\
Diabetic + S-150 & $4.54 \pm 0.06^{*}$ & $98.02 \pm 0.64^{*}$ & $53.46 \pm 1.49 *$ \\
Diabetic + S-300 & $6.07 \pm 0.12^{*} 121.40 \pm 0.77^{*}$ & $69.27 \pm 1.41^{*}$ \\
Diabetic + S-450 & $8.02 \pm 0.11 * 162.40 \pm 0.51^{*}$ & $92.44 \pm 0.45^{*}$ \\
\hline
\end{tabular}

SOD activity expressed as inhibiton percentage

Cat activity expressed as $\mu \mathrm{mol} \mathrm{H} 2 \mathrm{O} 2 \mathrm{~min}-1 \mathrm{~mL}-1$

GPH-px activity expressed as $\mathrm{mU}$ min-1 $\mathrm{mL}-1$

Values are expressed as mean \pm SEM.

$*$ : $\mathrm{p}<0.05$ vs control

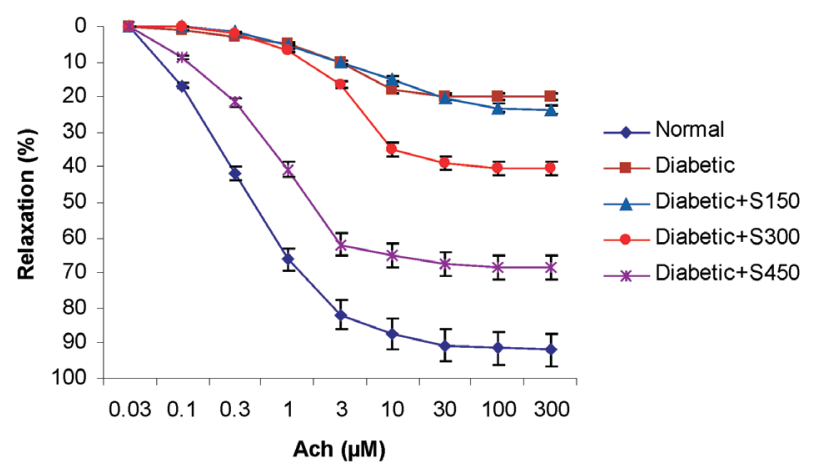

Figure 1. Concentration-response curves for $\mathrm{ACh}$-induced relaxation of aortic strips obtained from normal, diabetic and Sargassum echinocarpum extracttreated diabetic rats. The ordinate shows the relaxation of aortic strips as a percentage of the contraction induced by an equieffective concentration of NA. Each data point on the graph represents the mean \pm s.e.mean of 4-6 experiments.

\section{DISCUSSION}

In this study, administration of Sargassum echinocarpum extract for 12 weeks exhibited anti oxidative stress and increased Ach-induced relaxation

The diabetic rats showed decrease in the antioxidant enzymes, meanwhile, the diabetic rats treated with Sargassum echinocarpum extract showed significant increase in the antioxidant enzymes (Table 1). The antioxidant enzymes such as SOD, CAT and GPx are the first line of defense against $\mathrm{O}_{2}^{-}$and $\mathrm{H}_{2} \mathrm{O}_{2}{ }^{17}$ The levels of first line antioxidant enzymes were significantly depleted in diabetic rats. ${ }^{18}$ This deficient functioning of free radical scavenging enzymes leads to the accumulation of highly reactive free radicals and consequent degenerative changes. ${ }^{2}$ In the present study, the activities of SOD, CAT and GPx were significantly improved in diabetic rats that treated seaweed extract, which may support the defensive nature of the Sargassum echinocarpum extract against diabetic-induced serum oxidative stress. The effects of phloroglucinol on cell viability might involve dual actions: direct action on oxygen radical scavenging, as shown by $\mathrm{H}_{2} \mathrm{O}_{2}, \mathrm{OH}$ radical scavenging and indirect action through induction of antioxidant enzymes. Antioxidant enzymes would be potential target molecules mediating anti-apoptotic function of ERK pathway against oxidative stress. ${ }^{19}$

There is impairment of endothelium-dependent relaxation response to $\mathrm{ACh}$ in diabetic rat aorta. Several studies have indicated that the increased production of superoxide anions in vessels of diabetic animals and it is suggested that this active form of oxygen can inactivate NO to attenuate NO-dependent vasodilatory response in the diabetic rat aorta. Although the mechanisms underlying endothelial dysfunction may be multifactorial, there is a growing body of evidence that increased production of free radicals may considerably contribute to this phenomenon. Hyperglycaemia, being the characteristic feature of diabetes is one of the reasons for the increase the oxidative stress in diabetes. ${ }^{2,3,20}$

We found that the aorta rings of the diabetic animals treated with Sargassum echinocarpum extract showed significant increase in the endothelial dependent relaxation when compared with that of the untreated diabetic animals. The relaxation was comparable with that of the controls. Extract apparent modulates NO bioavailability in aorta diabetic rats. ${ }^{21}$ This indicates its protective role against oxidative damage in diabetes. 
Based on our findings, we suggest that Sargassum echinocarpum extract has the potential as a therapeutic component for treatment of diabetes and its complications. The mechanism of this effect involves enhancement of the antioxidant defence level and thus rendered protection from endothelial damage which is usually associated with diabetes.

\section{Ackowledgment}

This study was financially supported by General Director of High Education, Ministry of Education, Republic of Indonesia by Hibah Bersaing Program.

\section{REFERENCES}

1. Sydow K, Munzel T. Diabetes mellitus, oxidative stress and endothelial dyzfunction. Int. Congress Series. 2003; 1253: 125-38

2. Shi Y, Vanhoutte PM. Reactive oxygen-derived free radicals are key to the endothelial dysfunction of diabetes. Journal of Diabetes. 2009; 1: 151-62

3. Vanhoutte PM, Shimokawa H, Tang EHC, Feletou M. Endothelial dysfunction and vascular disease. Acta Physiol. 2009; 196: 193-222

4. RoghaniM,BaluchnejadmojaradT.Chronic epigallocatechingallate improves aortic reactivityof diabetic rats: Underlaying mechanisms. Vascular Pharmacology. 2009; doi:10.1016/j. vph.2009.01.003.

5. Maritim AC,Sanders RA, Watkins JB. Diabetes, oxidative stress and antioxidants: A review. J. Biochem. Mol. Toxicol. 2003; 17: 24-38

6. Laight DW, Carrier MJ, Anggard EE. Antioxidatns, diabetes and endothelial dysfunction. Cardiovasc. Res. 2000; 47: 457-64

7. Stoclet JC, Chataigneau T, Ndiaye M, Oak MN, El Bedoui J, Chatagneau M, Schini-Kerth VB. Vascular protection by dietary polyphenols. European Journal of Pharmacology. 2004; 500: 299-313

8. Anggadiredja J, Irawati S, Kusmiyati. Potensi dan Manfaat Rumput laut Indonesia dalam bidang Farmasi. Presented on Seminar Nasional Industri Rumput Laut, Jakarta, July 31, 1996

9. Smit AJ. Medicinal and pharmaceutical uses of seaweed natural products: A review. Journal of Applied Phycology. 2004; 16: 245-62
10. Singh IP and Bharate SB. Phloroglucinol compounds of natural origin. Natural Product Reports. 2006; 23: 558-91

11. Rice-Evans CA, Miller NJ, Paganga G. Antioxidant properties of phenolic compounds. Trends in Plant Science Reviews. 1997; 2: 152-59

12. Anggadiredja J, Andyani R, Hayati, Muawanah. Antioxidant activity of Sargassum polycystum (Phaeophyta) and Laurencia obtuse (Rhodophyta) from Seribu Islands. Journal of Applied Phycology. 1997; 9:477-9

13. Lim SN, Cheung PCK, Ooi VEC, Ang PO, Evaluation of antioxidative activity of extracts from a brown seaweed, Sargassun siliquastrum. Journal Agricultural and Food Chemistry. 2002; 50: 3862-6

14. Wei Y, Li Z, Hu Y, Xu Z,. Inhibition of mouse liver lipid peroxidation by high molecular weight phlorotannins from Sargassum kjelmanianum. Journal of Applied Phycology. 2003; 15: 507-11

15. Kang HE, Chung HY, Kim, JY, Son BW, Jung HA, Choi JS,. Inhibitory phlorotannins from the edible brown alga Ecklonia stolonifera on total reactive species (ROS) generation. Archives of Pharmacal Research. 2004; 27: 194-8

16. Iwashima M., Mori J., Ting X., Matsunaga T., Hayasih K., Shinoda D., Saito H., Sankawa U., Hayashi T. Antioxidant and antiviral activites of plastoquinones from the brown alga Sargassum microcantum, and a new chromene derivative converted from the plastoquinones. Biol. Pharm. Bull. 2005; 28: 374-7

17. Jakus V. The role of free radicals, oxidative stress and antioxidant systems in diabetic vascular disease. Bratisl Lek Listy. 2000; 101: 541-51

18. Karasu C. Increased activity of $\mathrm{H}_{2} \mathrm{O}_{2}$ in aorta isolated from chronically streptozotocin-diabetic rats: effects of antioxidant enzymes and enzyme inhibitors. Free Rad. Biol. Med. 1999; 22: 16-7

19. Kang KA, Lee KH, Chae S, Zhang R, Jung MS, Ham YM, Baik JS, Lee NH, and Hyun JW. Cytoprotective Effect of Phloroglucinol on Oxidative Stress Induced Cell Damage via Catalase Activation. Journal of Cellular Biochemistry. 2006; 97:609-20

20. Rebecca AS. Serial Review: The role of oxidative stress in diabetes mellitus developmental origins of diabetes: The role of oxidative stress. Free Radic. Biol. Med. 2006; 40: 917-22

21. Stoclet JC, Chataigneau T, Ndiaye M, Oak MN, El Bedoui J, Chatagneau M, Schini-Kerth VB. Vascular protection by dietary polyphenols. European Journal of Pharmacology. 2004; 500: 299-313 